\title{
Job, Zeisl, Exile, and the Suffering of the Ordinary
}

\section{MICHAEL BECKERMAN}

Mendel Singer, the protagonist of the Josef Roth's 1930 novel, Job gets out his phylacteries, takes off his prayer shawl, and prepares to throw both into the fire. He wants to burn them, but cannot bring himself to do so. Instead he curses the Almighty: "God is cruel, and the more one obeys Him the more brutally He treats one. He is mightier than the most mighty; with the nail of one of His little fingers He can wipe them out, but He does not do it. Only the weak He gladly destroys. The weakness of a man tempts His strength and obedience awakens his scorn." And why shouldn't Mendel Singer, a "pious, ordinary and utterly commonplace man" from Galicia curse the Lord? Didn't he have four children who broke his heart; Jonas, a soldier who drank vodka with the peasants; Shemaria, interested only in money; Miriam, who lies with soldiers in the fields, and poor crippled Menuchim, deformed and mute? Hasn't the flesh of his wife, Deborah become alien to him? And didn't the whole family move to America, abandoning poor Menuchim, only to confront an endless wave of sorrows?

The composer Eric Zeisl encountered Roth's Job in Paris in 1939 when the director Paul Gordon asked him to write some incidental music for a staged version being put to honor the author just after his death. Himself a recent exile from Vienna, where he had enjoyed considerable early success, Zeisl quickly came to identify with Mendel Singer, and also with his mute but somehow visionary son, Menuchim. For the remaining 20 years of his life the composer worked on and dreamed of a great opera based on the novel.

After Mendel Singer curses God, his soul shrivels. His wife dies and he lives as a kind of barely tolerated boarder in the house of a friend. One day, he hears something new on the gramophone: "It ran like a little brook and murmured softly; it was vast as the ocean and roared. Now I am hearing the whole world, thought Mendel. How is it possible that the whole world can be engraved on such a little disc? Then a silver flute tone melted into the violin music; it sewed itself around the velvety fabric of the violin playing like an accurate little hem. Mendel began, for the first time in a long while, to weep."

And when Mendel looks at the label of the record, he sees that it is called "Menuchim's Song." He has no idea what this means.

This imaginary song, made audible, becomes the core of Eric Zeisl's opera project and it pushes the composer in a new direction, something he characterizes as "music in a romantic religious vein." More specifically he states that, "The story of the persecuted Jew who escaped from Poland to America suggested in itself an outspoken Jewish music." This music was "something like a prayer": 


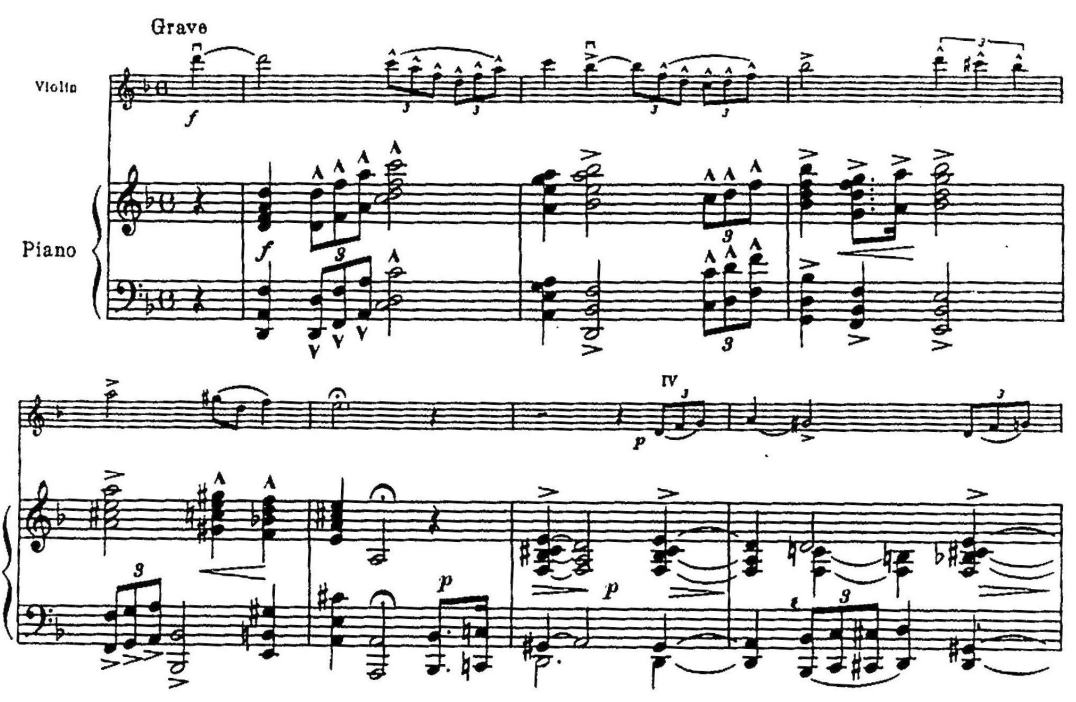

Example 1: "Menuchim's Song"

Listen at: http://dx.doi.org/10.3998/mp.9460447.0005.204

Over the next twenty years, this Hebraized mode becomes one of the most pronounced colors of Zeisl's compositional palette, appearing notably in his most successful composition, the Requiem Ebraico, and in many of his other works such as the "Brandeis" Sonata and the Andante of the Second String Quartet.

But perhaps there is actually more than one kind of "Jewish mode" present in Zeisl's work and this leads us again to Roth's Job. The mystery of "Menuchim's Song" is cleared up towards the end of the novel. Menuchim, long thought dead, has not only survived but has become a successful composer. His transformation from Jewish invalid to cosmopolitan celebrity is marked by his highly ironic new name, Alexis Kossak. And in Zeisl's interpretation, his music, like his name, has the aroma of assimilated exile, retaining hints of its Judaic background, but heard through the scrim of contemporary (and somewhat conservative) symphonic style. (We may note that Roth's "Menuchim" with the voiceless pharyngeal fricative "ch" is replaced by Zeisl with the assimilated "h" as "Menuhim.")

It is no wonder that Job remained on Zeisl's mind throughout his time in the United States, for his American experience bears certain rough similarities to the protagonists of Roth's novel. Though the composer's experience was not as brutal as Mendel Singer's, it certainly was not easy. Early success never translated to a permanent position or real stability; he was no Alexis Kossak. The enticements of the film industry mired the composer in frustrating piecework; he wrote travelogues, but he never got even a single major screen credit, though he did write the title music to "The Postman Only Rings Twice."

Many times Zeisl must have been tempted to utter the words of Roth's hero: "I am no longer Mendel Singer. I am but the remains of Mendel Singer. America has killed us."

In order to explore how Zeisl's dance of assimilation and exile played out in his compositions, let us settle on the year 1956, some 17 years after the Job music was first conceived in Paris and three years before the composer's sudden death at the age of 53. Things are going better for Zeisl; he gets various 
fellowships and stipends. In the summer he vacations at Arrowhead Lake in California. Here he writes a Trio for flute, viola and harp. The outer movements are quasi barocco, short and light:

Example 2: Arrowhead Trio, I. Allegretto (beginning)

Listen at: $\underline{\text { http://dx.doi.org/10.3998/mp.9460447.0005.204 }}$

Example 3: Arrowhead Trio, III. Finale (beginning)

Listen at: http://dx.doi.org/10.3998/mp.9460447.0005.204

It is in the sensuous slow movement, however, that we hear the assimilated exile:
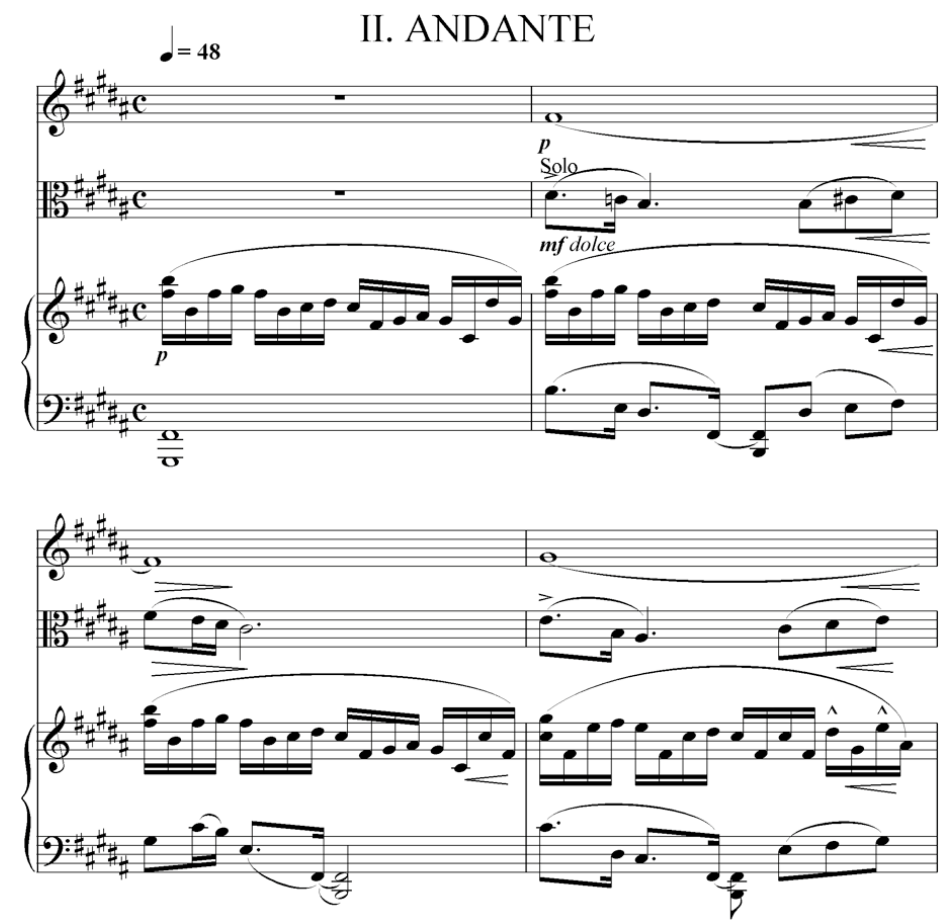

Example 4: Arrowhead Trio, II. Andante (beginning)

Listen at: http://dx.doi.org/10.3998/mp.9460447.0005.204

Here, the marked Hebraic material appears, then vanishes as if it had never been there in the first place. Menuchim-the-deformed almost immediately becomes Kossak-the-redeemer. But there is another kind of music in the center of the Trio's slow movement not so easily brought into line with mainstream values and style. We may approach this by once again considering the Book of Job itself, and a more recent cinematic echo of it.

In the Coen Brother's film A Serious Man, the Job (and Mendel Singer) figure, Larry Gopnik, is clearly doomed. A victim of crushing Divine bullying in 1960's Minneapolis, his downward spiral, like the film's final tornado, is endless, inescapable and brutal. Larry is a post-holocaust Job, to be sure.

Roth's novel, however, inhabits an uncanny nether realm. Written in 1930, it imagines a world, an American world, with a future in which no Holocaust ever happens. Thus Menuchim survives, 
straightens out, speaks and thrives. Mendel Singer is reborn, he becomes respected, "a serious man" himself. As the novel ends, Menuchim is on his way to the asylum to bring the compromised Miriam back to a pure version of her former self, and make the family whole again.

It would be easy enough to conclude that the differences between Roth's Job and the Coens' has to do with historical timing: Mendel can be saved, Larry Gopnik, never. But this would ignore another kind of music in Roth's novel. Mendel's second son, Shemariah, who as "Sam" has become the family savior, is killed in the war. When, on a cold New York winter day, Mendel's wife receives the news, she begins to tear out her hair:

One after another she rent the strands of hair, one after another, in the same tempo in which, outside the flakes were falling. Two, then three, white islands appeared amidst her hair, a few spots the size of a dollar where the naked scalp showed, and a few tiny drops of red blood. No one moved. The clock ticked, the snow fell, and Deborah quietly tore out her hair.

Out of this immense and devastating silence, this utter depth of suffering, Deborah begins to sing; but her song is worlds away from Menuchim's tale of redemption:

She sang in a deep, male voice, which sounded as though there were an invisible singer in the room. The strange voice sang an old Jewish song without words, a dark lullaby, for dead children.

Perhaps it is this song we are meant to hear in the very middle of the Arrowhead's Trio's slow movement, a song too marked, too strange and alien to ever be assimilated into the common world.

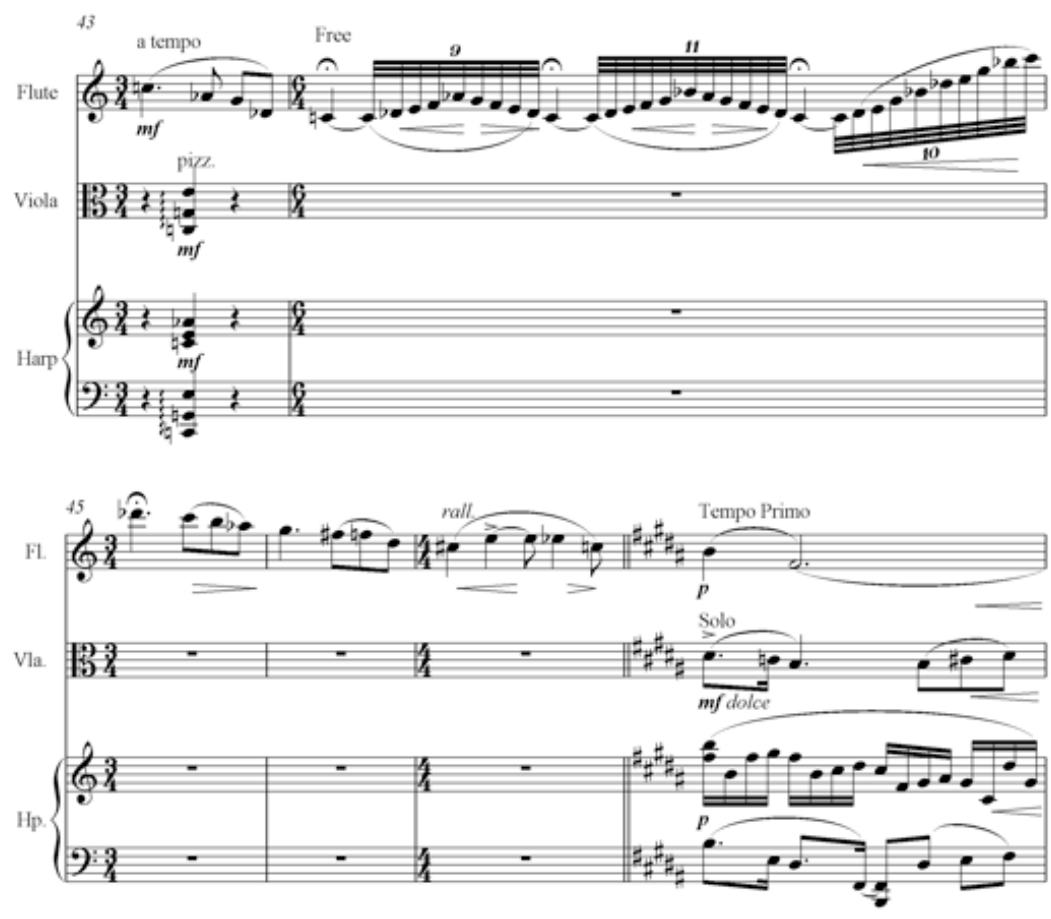

Example 5: Arrowhead Trio, II. Andante (middle)

Listen at: $\underline{\text { http://dx.doi.org/10.3998/mp.9460447.0005.204 }}$ 
Even though Zeisl never got around to setting the scene of Deborah's desperate mourning, her Lullaby in Act II, Scene 2 bears a family resemblance to it. It is perhaps not too much of a stretch to imagine Zeisl's flute setting as a devastating variation on the lullaby:
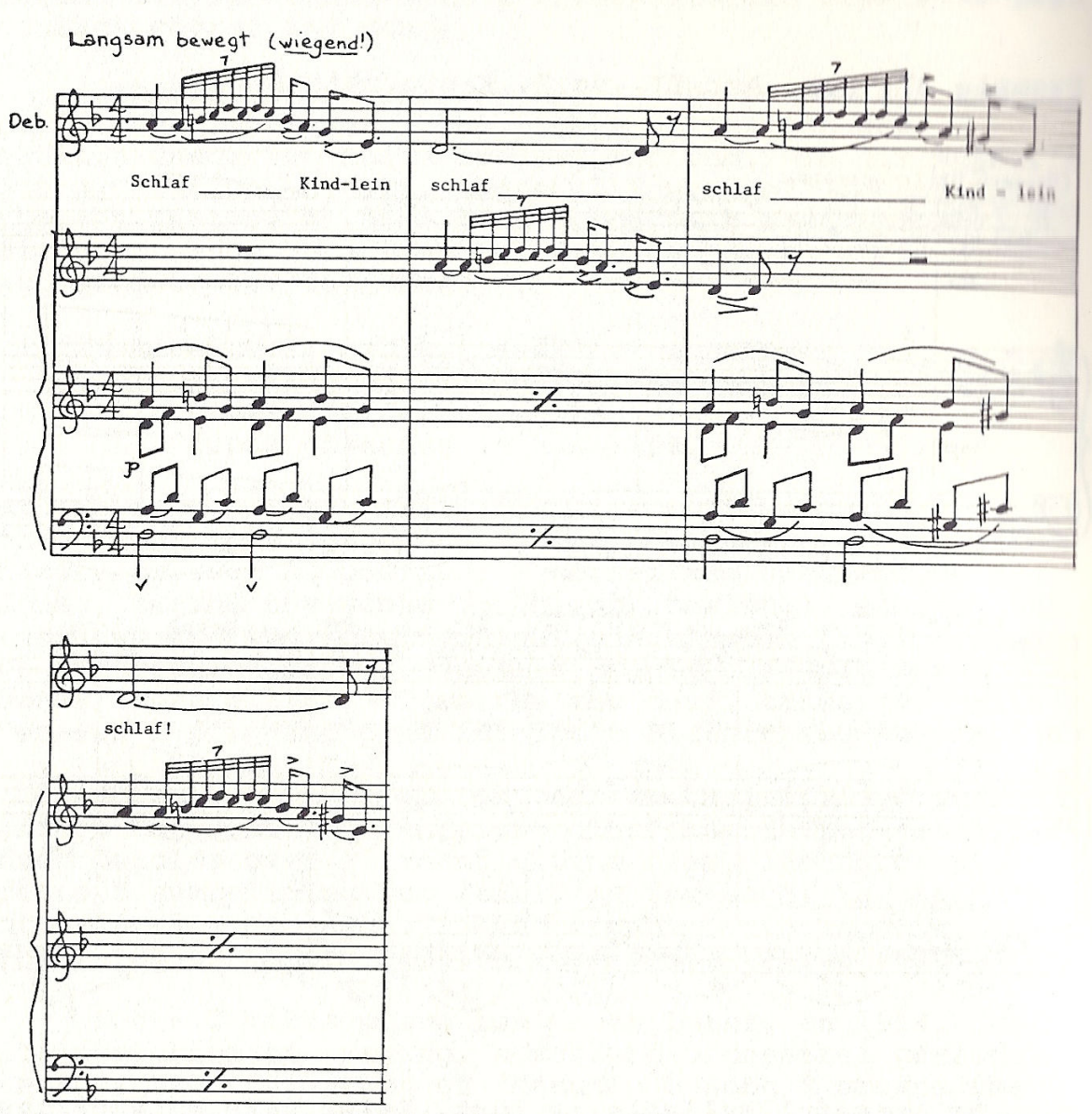

And it may be this unassimilated mode that is made audible at the opening of the Andante of the Second String Quartet, described by the composer as a dialogue between God and man.

Example 6: Second String Quartet, II. Andante (opening)

Listen at: $\underline{\text { http://dx.doi.org/10.3998/mp.9460447.0005.204 }}$

It seems fitting that Zeisl chose Roth's Job as his central text. Though by no means a simple man, he certainly stands in sharp contrast to his daughter's father-in-law, Arnold Schoenberg. Schoenberg's ambition and influence made him dwell on the issue of the prophet, and took him naturally to a subject like Moses and Aaron. Zeisl, who really felt he and his fellow exiles deserved better at the hands of publishers, concert promoters and studio executives, concerned himself more with the issue of why the good and the righteous suffer. As this question is not resolvable it is fitting that only in the interior spaces, in both Roth's novel and the "Arrowhead" Trio, something of the excruciating reality of exile is depicted, a core of difference and alienation that can never be redeemed or even publicly confessed. Such a Menuchim-like deformity can only go into the center of things. 
To be sure, Zeisl had many happy times in the United States. His home became the center of a sparkling émigré circle; his family life was happy. Yet he remained forever injured, calling Hollywood "a sunny blue grave." He died just as his teaching position at Los Angeles City College was being mysteriously phased out due to what we now understand were questions relating to tenure (even the Coen's Larry Gopnik had better luck in this sense).

Unlike the slighter "Arrowhead" Trio, the vast canvas of Job remained unfinished, like Moses and Aaron, and it was in some sense, unfinishable. Zeisl hid his pain well, but it is my sense that in the lowest register of the Arrowhead's flute we are confronted with the perversion of a possessed woman singing her male demon, an unassimilatable dybbuk that reveals Zeisl's view of how things really stood in his new found land. 


\section{Sources}

This article is not intended to be a complete treatment of the issues, sources, and realities surrounding the story of Zeisl and Job. However, there are a set of materials, including several online, that put most of the available information about the opera together. Many of these may be found by exploring the Zeisl website at: http://www.zeisl.com/index.htm This site offers everything from biographical material to a library of mp3 recordings of Zeisl's works.

The main source for much of the biographical material relating to Zeisl's Job is Getrude Zeisl's reminiscences as told to Malcolm Cole. Cole interviewed the subject over several weeks from August to September 1975 resulting in about twelve hours of taping which was then transcribed. It is now available at: http://www.archive.org/details/ericzeisloralhis00zeis

The interviews may be accessed in several formats. Gertrude Zeisl makes it clear several times that Zeisl never gave up the idea of completing the work, for example, "the idea of finishing this opera was always very close to his heart and never left him completely, and that there was never a year in which he didn't try in some way to get back to this work." Gertrude Zeisl traces the various attempts to complete it and the reasons it remained unfinished.

Another important source for Zeisl research is Endstation schein-heiligenstadt: Eric Zeisls flucht nach Hollywood, a catalogue published in conjunction with "vienna, california eric zeisl's musical exile in Hollywood," an exhibition at the Jewish Museum Vienna which ran from November $20^{\text {th }}, 2005$ to March $26^{\text {th }}, 2006$. The catalogue is available online: www.zeisl.com/files/2559 05 Jued_Museum_Kat_Cover.pdf

On the question of why the work remained unfinished, Michael Haas, the curator of the exhibit, makes an intriguing point when he suggests that, considering that Zeisl's father had perished in the camps, the composer found it difficult to finish an opera which dealt with the redemption of a father by his son:

Zeisl's father and his second wife were murdered in the Nazi death camps before visas and arrangements could be made to get them out of Austria. His most beautiful and moving work, Requiem Ebraico, was composed in their memory and inevitably reflects the difficulty of writing an opera, the happy ending of which is the salvation of the father by the son. Job was a work on many levels for Zeisl. On its surface, it was the story of the Jewish people's fate in the Diaspora and their search for identity. Yet Zeisl's own experiences after 1938 meant that the individual characters of Mendel the father and Menuhim the son would have had a powerful hold over his imagination. The closeness of the subject must surely have made continued work virtually impossible (p. 20).

The most detailed treatment of the music may be found in Malcolm Cole and Barbara Barclay's Armeseelchen, published by Greenwood Press in 1984, particularly in chapter "Dramatic Compositions," from pp. 195-219. Despite this excellent introduction 
to the opera's musical languages, there is a rich trove of materials that still have not been explored.

Considering that he is not usually considered among the giants of $20^{\text {th }}$ century music, Zeisl has attracted a considerable amount of excellent scholarship. Karin Wagner, a leading figure in Zeisl research writes perceptively about his musical orientation in an article in the exhibition catalogue titled Eric Zeisl (1905-1959) - Life and Works: "In his new compositions, Organ Prelude and Menuhim's Song, which he wrote for Job, he abandoned the Viennese style that had characterized his work hitherto and unmistakably embraced a more Jewish idiom.”

The source materials for Job are available at the Erich Zeisl Archive in Special Collections at UCLA in several boxes as indicated in the Guide to the Zeisl Papers: http://www.oac.cdlib.org/findaid/ark:/13030/kt5c60215z/

I have previously dealt with some of the issues discussed here, though not in relation to Job, in "Ježek, Zeisl, Améry and The Exile in the Middle," Music and Displacement (Scarecrow Press, 2010).

To my knowledge the completed scenes from Job have never been performed in their entirely. However, in 2009 several scenes were performed in Wien-Rostok. Information about this is available at: http://sumusnet.eu/index.php?/english/hiob-wien-rostock/

Roth's Job is available in English in a new translation by Ross Benjamin (New York: Archipelago Books, 2010) which seems to have replaced Dorothy Thompson's translation, made a year after the novel was originally published and until recently widely available (Woodstock \& New York: Overlook Press, 2003). The novel was originally published in German by Gustav Kiepenhauer Verlag AG, Berlin in 1930. For a brief comparison of Thompson and Benjamin's translations see:

http://quarterlyconversation.com/job-by-joseph-roth

I have used Thompson's translation in my article.

As usual the author is grateful to several people for their help with this project including Robert Elias, the Executive Director of the OREL Foundation, and to Barbara Zeisl Schoenberg for her help in getting Zeisl material. 